\title{
COVID-19 containment measures of the Government of Kenya: Impact on food security and farmers' socio-economic life
}

\author{
Kebijakan penanggulangan COVID-19 pemerintah Kenya: \\ Dampak terhadap ketahanan pangan dan kehidupan sosial ekonomi petani
}

\author{
Karen Mwende Kinuthia \& Emy Susanti* \\ Department of Sociology, Faculty of Social and Political Sciences, Universitas Airlangga \\ Address: Jalan Dharmawangsa Dalam, Airlangga, Surabaya, East Java, Indonesia 60286 \\ E-mail: kinuthia.karen@yahoo.com \& emy_susanti@yahoo.com*
}

Article History: Received 21 July 2020; Accepted 10 March 2021; Published Online 19 April 2021

\begin{abstract}
Agriculture is the backbone of Kenya's economy. The majority of the population earn their living through agricultural activities, large-scale and small-scale farming. This study seeks to reveal how the government's COVID-19 containment measures have affected the agricultural sector and their impact on farmers' lifestyle changes. This study employed qualitative research methods, with primary and secondary data sources, and conducted in-depth interviews with 12 farmers and agricultural producers of Gatanga Sub-county in Murang'a County, Kenya. This study shows that the farmers experienced economic shocks owing to the fluctuated farm gate prices and projected resource scarcity. In contrast, their lifestyle changed due to income decrease and adjustment of commodity priorities and socio-demographic factors. The severity of COVID-19 impact on agriculture in the Gatanga Sub-County has been doubled by crop destruction, planting delays, and heavy rains that influence scarcity of food commodities. The study recommends other research to evaluate alternative solutions to supply the county's food outputs other than those already in co-operatives, like tea, coffee, milk, and avocados. Moreover, perhaps the question for other future researchers should now be directed toward the vulnerable families' daily consumptions to fulfill their food needs.
\end{abstract}

Keywords: agriculture; consumption; COVID-19 impacts; food security; food supply

\begin{abstract}
Abstrak
Pertanian merupakan tulang punggung ekonomi Kenya. Sebagian besar penduduk hidup dari kegiatan pertanian dalam skala besar dan kecil. Studi ini berusaha untuk mengungkap bagaimana tindakan pemerintah dalam penanggulangan COVID-19 telah memengaruhi sektor pertanian dan dampaknya terhadap perubahan gaya hidup petani. Studi ini menggunakan metode kualitatif, dengan sumber data primer dan sekunder, serta dilakukan wawancara mendalam dengan 12 petani dan produsen pertanian Kecamatan Gatanga di Kabupaten Murang'a, Kenya. Studi ini menemukan bahwa para petani mengalami guncangan ekonomi akibat fluktuasi harga pertanian dan memperkirakan kelangkaan sumber daya, sedangkan gaya hidup mereka berubah karena berkurangnya pendapatan, penyesuaian prioritas komoditas, tetapi juga ditentukan oleh faktor-faktor sosio-demografis. Tingkat keparahan dampak COVID-19 pada pertanian di Gatanga telah berlipat ganda oleh kerusakan tanaman, keterlambatan tanam, dan hujan lebat yang memengaruhi kelangkaan komoditas pangan. Studi ini merekomendasikan penelitian lain untuk mengevaluasi solusi alternatif untuk pasokan makanan seperti teh, kopi, susu dan alpukat. Selain itu, perlu dilakukan studi yang difokuskan pada jumlah konsumsi harian keluarga rentan agar kebutuhan pangan terpenuhi.
\end{abstract}

Kata kunci: pertanian; konsumsi; dampak COVID-19; keamanan pangan; persediaan makanan

\section{Introduction}

Agriculture has been the principal means to an end venture for most Kenyan families, primarily rural areas. Although several impacts of COVID-19 preventive measures were felt instantly with the closure of schools, airports, bars, and restaurants in Kenya upon announcement of the first case, there are other impacts slowly materializing as the months' pass and the increase of reported COVID-19 cases, such as economic crisis, rise in social crimes, especially online frauds, and the threat to Kenyan food security. Food security has been put in a precarious position due to disruptions arising from the pandemic (Zurayk 
2020). According to World Food Summit (FAO 1996), food security exists when all people, at all times, have physical and economic access to sufficient, safe, and nutritious food that meets their dietary needs and food preferences for an active and healthy life. The dimensions of food security include the availability of adequate quantities and appropriate quality of food, accessibility of food, food utilization through adequate diet, clean water, and sanitation, the stability of food access at all times with loss to accessibility not threatened by climatic and economic crisis (FAO 2006). Njeru and Ayieko (2020) postulate that Kenya's worst food insecurity situations were experienced in 2017 and 2008. In 2017, the rainfall delay, followed by little rainfall, was attributed to low productivity on heavily rain-dependent farming. These two years had the highest deficits in food production and food prices.

With the daily increase of COVID-19 cases in Kenya, food deficits may reach similar 2008 and 2017 magnitudes. The COVID-19 reported cases as of 24 June 2020 in Kenya stood at 5.206 with recovered cases amounting to 1.823 , with Murang'a County only having three new cases as briefed by the Health Cabinet Secretary (Kimuyu 2020). The United Nations (2015) Sustainable Development Goals (SDGs) have all been adopted by counties within Kenya. Murang'a County engineered its programs and projects toward achieving the 17 goals. The onset and progression of COVID-19 within Kenya have hampered the actualization of sustainable development goals. This study focuses on the first and second goal: 1) first goal, which is to end poverty in all its forms everywhere, stands to be undermined by the pandemic as economic activities are affected by the number of regulations initiated to curb disease spread and 2) second goal, which is end hunger, achieve food security, improve nutrition and promote agriculture (County Government of Murang'a 2018), has also been intensely undermined by the progression of the disease as normal activities have either been minimized, completely stopped or postponed. For a short period, a coronavirus's food security threatens with down-sized work hours and salary cuts affecting farming as farmers receive reduced revenues and farm inputs become unaffordable (Meeme 2020).

Besides the SDGs initiatives, Kenya's national government set up the big four agenda, which consisted of four priority areas to be reformed within the 2018-2022 government term. The agenda includes enhancing manufacturing, food security and nutrition, universal health coverage, and affordable housing for all following the Kenya Vision 2030. Undoubtedly, this has been hampered by COVID-19 prevention measures. The second agenda focused on food security and nutrition provision initiatives to all Kenyans by 2022 through expanding production and supply of food, reducing food prices to enable affordability, and support value addition in the food processing value chain. Correlates with this study aim to find out to what extent the food supply chains and agricultural activities have been affected by the regulatory measures of controlling the spread of coronavirus. The food supply chain has taken the worst hit of the COVID-19, posing a threat to food security, especially among the most vulnerable groups. In some countries, most of the migrants, seasonal farmworkers, lost their jobs, which, in turn, may affect demand (Poudel et al. 2020).

In a bid to control crowding, which increases the risk of disease spread, markets closed in the urban and semi-urban areas, disrupting supply chains of food, mainly fresh farm produce. Njeru and Ayieko (2020) noted that the disruptions were most adverse for low-income urban settlers whose consumption was highly reliant on informal food markets. Conversely, middle and low-income homes buy produce from supermarkets, online markets, and greengrocers, which remain open. For traders and farmers, in March 2020, the government announced that the markets would remain open so long as traders observed protocols of distancing and hygiene (Munyao \& Wanjiru 2020); however, the closure of markets in other counties affected business trade since farm produces from Murang'a, like arrowroots, is sold in Thika and Nairobi markets.

The Kenyan government-imposed curfew hours in June from $9 \mathrm{pm}$. to $4 \mathrm{am}$. In some counties like Wajir, which are entry and exit points of commodities from and to other East African countries, the dusk-dawn curfew, heavy rains, and passenger mobility restrictions were partly to blame for the rise in commodities' prices. Just like passenger flights were used commonly to export commodities, passenger vehicles were also used to transport food within Kenya, and the suspension of these vehicles has affected the flow of 
goods. Predictions, as per Meeme (2020), were that in urban areas and other areas without agricultural backgrounds, the consumption prices go up as an effect of supply decrease and panic buying, while in the rural areas, prices of products go down, as a result of the reduced movement of goods and buyers.

For instance, the closure of both interstate and intrastate borders, such as the closure of the MoyaleEthiopia border, which was also caused by heavy rainfall, disrupted the supply of maize commodities, onions, and tomatoes into Kenya (World Bank 2020). Not only has importation been affected; however, for exportation of produce from Kenyan farms to other countries. Three-quarters of horticulture exports from Kenya to Europe consist of fruits, vegetables, herbs, and flowers (Roussi 2020). Exports in Murang'a have been affected immensely; the county is known to produce fruits like passion fruits, mangos, pineapples, herbs like rosemary, mint, and even vegetables such as French beans for export. In 2017 and 2018, fruits and vegetables earned 12.83 billion KES and 27.68 billion KES, respectively; however, in 2020, this product's shipment ceased in March after the European countries went under lockdown (Roussi 2020).

On the other hand, the exportation of flowers in 2018 contributed 113.16 billion KES or 1.1 billion USD, indicating a $37.8 \%$ growth rate (APA News 2019). In 2020, the rhythm of exports had drastically changed. The Kenya Flower Council reported a decrease in operation up to less than $10 \%$ in 2020 as their largest markets are closed. This market is also affected by a few cargo planes, reduced consignment volumes, and competition from other products from other countries (Wahome 2020). Wahome (2020) found that the pandemic's agriculture sector is the billion-dollar horticulture sector that produces flowers, mainly for export to Europe. The demand decrease has caused work layoffs for many women, unpaid leave, and even rotating work routines with little pay. Most of these families' livelihoods have been hampered, and the current situation's longevity could trigger further detriment (Wahome 2020). In the Gatanga sub-county, several horticulture flowers such as Enkasiti roses and Simbi roses were inevitably hit by reducing exports.

Apart from border restrictions, the closure of agri-business has also negatively impacted the agriculture sector's progress. Wasike (2020) found that, in farming sectors, planting season was delayed, which may result in starvation as harvest season will also be later than the usually determined seasons. Small-scale farmers have experienced losses of their harvested fresh produce and the inability to acquire farm inputs like fertilizers and high-grade seeds for plantation due to measures such as the closure of cross-country travel, which hinders access to far-away markets. Some farmers reported that, with the closure of agribusinesses, for example, seed vendors, pesticides and fertilizers dealers, and tractors' operations, they lacked planting inputs.

The shortages of farm inputs have been felt within Kenya and beyond, courtesy of global trade disruptions resulting from COVID-19 preventive measures. Such farm inputs, like pesticides, seeds, and even fertilizers, are mainly produced and exported from China. These shortages have taken a toll on spring crops' plantations like sunflowers, canola, wheat, maize, and barley (Poudel et al. 2020). As of midMarch 2020, the future of food security was already projected as the strategic food reserve oversight board recommended importing maize as speculation arose on a potential flour crisis within the rest of the year (Andae 2020). The restrictions on-road travel delay livestock feeds to rural areas far from Nairobi, while air travel restriction has hampered the import of livestock vaccines from Egypt, Japan, and India (World Bank 2020). Pakistan's export ban has stopped Kenya's importation of rice from Pakistan; other countries, Kazakhstan, have also stopped exporting some products, such as oilseeds, wheat flour, and vegetables. Vietnam has also canceled exportation certificates on rice products until the end of March (Barichello 2020).

The COVID-19 pandemic challenges were tripled by locust invasion in some regions and the heavy rains that took place at the end of March to early May within Kenya. Although some traders stocked up supplies in anticipation of projected road damage, some were caught unprepared. In reflection of the definition mentioned early, Kenya's food security is currently threatened by economic changes, 
locust invasion, and recent flooding and landslides. Although Murang'a has not been affected by the unwarranted locusts, the county, including the Gatanga region, has as recently as May, been affected by flooding and landslides, which delayed planting and destroyed mid-growth plants like arrowroots, vegetables, and maize which are planted near the valleys or downhill; however, those who had planted vegetables and maize uphill were able to salvage some for consumption. Gatanga is part of the Western region of Murang'a County, which is wet and humid as a result of proximity to Aberdares and Mount Kenya, which supports the agricultural activities of such crops like tea, arrowroots, maize, coffee, vegetables, fruits, and nuts (Murang'a County Government 2017, County Government of Murang'a 2018). This research will evaluate farmers' situation in Gatanga Sub-County, Murang'a County in Kenya, to establish how the effects of pandemic control regulations have changed their lifestyles, income, and overall resource surplus in the county.

\section{Research Method}

Murang'a is one of the forty-seven counties of Kenya and locates along Kenya's highlands, where the weather and land are favorable for agriculture (Figure 1). Gatanga is one of the six constituencies of Murang'a County, and it locates in the western part of the county. Therefore, the domineering economic activity amongst Murang'a residents is agriculture. People in this region are mainly farmers of coffee, tea, maize, avocados, macadamia, bananas, arrow roots, sweet potatoes, vegetables, among other crops. The majority of the residents keep livestock, mainly dairy cows, traditional chicken, namely kuku kienyenji, broilers for eggs and meat, and goats. To encourage farmers to embrace more modern, profitable agribusinesses, the Murang'a County government put initiatives for the sustenance of agriculture in the region. For instance, milk prices being standardized for 35 KES per liter, also the formation of an avocado farmers' co-operative enabled prices of avocados to rise from 2 KES to $10 \mathrm{KES}$; the county is also working toward improving coffee standards through the provision of improved seedlings and organic manure at standardized prices (County Government of Murang'a 2018).

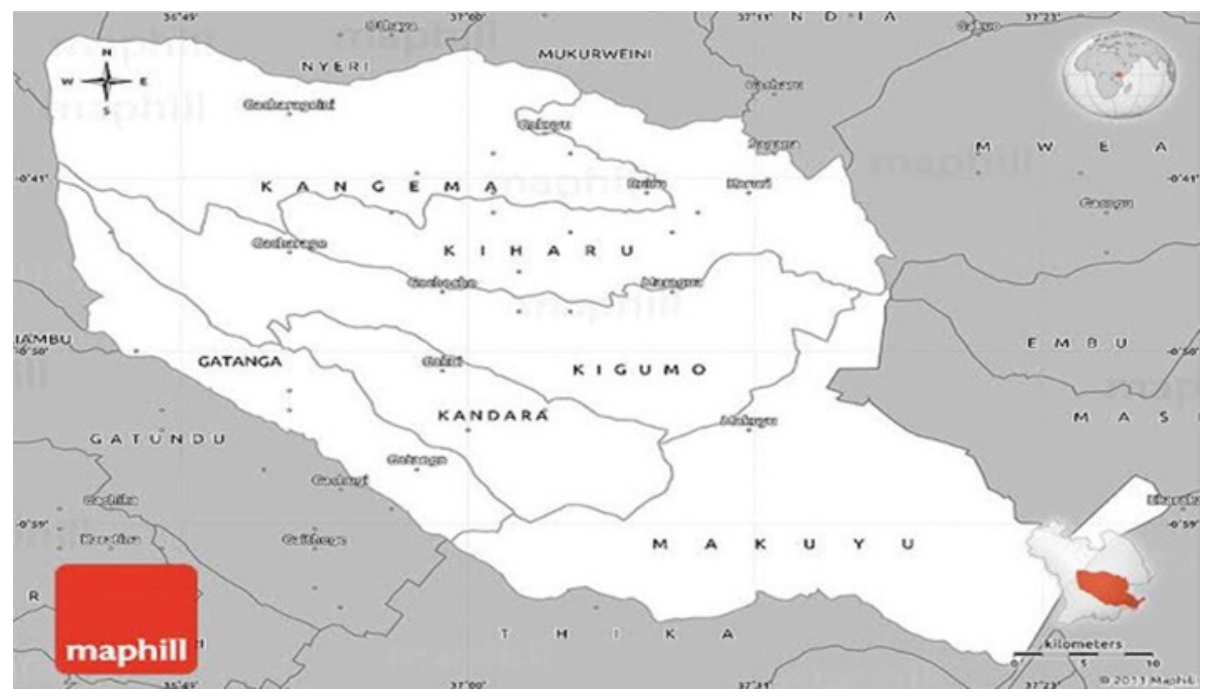

Figure 1.

Murang'a County map showing location of Gatanga Sub-County

(Murang'a County is the region in white background) Source: Maphill (2011)

The data were collected through primary sources and reviewing secondary sources from mass media (news outlets) and food and agriculture organizations' weekly reports. The primary data collected through in-depth interviews recorded, and in some cases, follow-up interviews were carried out. Gatanga SubCounty was selected because agriculture is the main economic activity in Murang'a County. Sampling used a purposive sampling method with 12 informants, all of whom live in Gatanga District, and all of 
whom share similar farming activities, small-scale farming for subsistence and sale purposes, and a few livestock for the production of milk, eggs, and meat; however, apart from farming, some have regular jobs, all of which have been disrupted by COVID-19 precautions. The twelve participants included a teacher who is a farmer and has employed one farm laborer, a shop- keeper with her husband who employed in local butchery--together they own a farm, a greengrocer at a local market who also owns a farm, a mother of 12 children who is a full-time farmer, and an older woman living alone since her adult children live in the city, and five full-time small-scale farmers of tea, coffee, avocados, and macadamia. Data collected were analyzed through thematic analysis. The central theme was socioeconomic issues and economic shock; other sub-themes were categorized under social issues; these were lifestyle changes, and under economic shock, the sub-themes were resource scarcity changes in farm gate prices.

\section{Results and Discussion}

Social issues are problems that affect a particular society. The consequences of these problems exceed the capability of individual control. These consequences negatively affect many people and are recognized as conditions in dire need of reformative action (University of Minnesota Libraries 2010). Although distinguishable from economic issues, some of these social issues contain social and economic aspects. Such is the case for this study; the disruptions in agricultural activities have affected income-generating ventures, affecting farmers' social aspects.

\section{Lifestyle changes}

A rural environment has different lifestyles in comparison to urban areas. This study's lifestyle aspect reflects the change in consumer lifestyle due to the regulations to control the spread of coronavirus. The six informants recounted their experiences with voluntary and involuntary food consumption changes and other products and services, such as electricity, water, electronics, other house appliances, and items. Larger families with low incomes are experiencing the effects of COVID-19 at an adverse rate. One of the respondents, who is a full-time farmer and mother of 12 children, stated: "I have had to cut out the amount of meat we eat, even though the prices of beef remained the same, we prefer to buy more vegetables than to buy a Kilograms of meat."

The family's unfortunate change of lifestyle is because most of the adult children work in the public transport industry as drivers, and, with travel restriction, the usual steadiness of their nature of work has been interrupted as fewer people are traveling. In addition to uncertainties in their jobs, the adult children have their wives and children, making it even harder to support their parents and younger siblings. The low-income family would afford occasional beef treats; however, as of June 2020, they only rely on farm produce and buy some beans, maize, and maize flour as everyday meals. Socio- demographic factors contribute to the impact felt with each family individually.

Such factors as employment status, family size, socioeconomic status (education and income levels) determine how a family is affected by new protocols issued to limit exposure risk. An example would be the different incomes earned from different plantations; those farmers who sold coffee were more vulnerable to income shortages than tea farmers because tea farmers got monthly payments from factories and an additional annual bonus at the year-end. The tea farmer gets $15 \mathrm{KES}$; hence, the more extensive the tea farm and quantity production, the higher the monthly income and the higher end-year bonus; however, with coffee being seasonal, it is only harvested at the end of each year, and the payments are released the following year; in some parts of Murang'a, the coffee farmers were paid for the 2019 harvest in April, with each Kilogram at $33 \mathrm{KES}$, a decline from $56 \mathrm{KES}$. A full- time farmer said:

"If I did not have my small tea section, the last year's coffee returns would have been very devastating, we were paid very little money, and my farm is no longer big enough because I gave half of my 2.5 hectares to my son when he married." 
Hence, small coffee farmers were cutting losses as they returned home. When COVID-19 changes food production's availability and distribution, low-incomes potentially subject families to uncertainties of their future food affordability. With Kenya being the second largest tea exporter after China, most of its tea is imported by Egypt, the United Kingdom, Pakistan, and the United Arab Emirates, and the sector remains stable amid the COVID-19 crisis. The fear was that any spread among the tea pickers could disrupt tea picking's daily activities (African Business 2020). Post COVID-19, most of the tea pickers are also lacking jobs, a tea or coffee farmer reported:

"Sometimes I employed tea pickers to help to pick tea depending on the quantity of each week, and I can hire two to three pickers, now that my daughters are home, we all go to pick together. I use that money to buy flour and other necessities instead of hiring; the times are tough."

The farmers stated that the whole family capacity was fully utilized in house chores and farm work and for the shopkeeper, even the shop duties. Only the teacher was able to keep a laborer, he stated:

"I have to keep him at the farm, I have some cows, goats, chicken and the farm and on my own, I cannot carry out all these activities; all the farm is making losses and the little profit it makes I pay him because going to the city to collect salary is a bit risky," (Sos, a teacher and part-time farmer).

The decline worst hit the families whose only income source was farming in specific commodities prices. A respondent who was a teacher and a farmer stated that she is still receiving a full salary, and although her farming losses owing to the flood and changes in demand and supply chains of her farm produce may have changed her usual farm returns, she still could afford to purchase an assortment of fruits, vegetables, and meat. She said:

"I shop every Sunday, which is the main market day in the area. I buy fruits, vegetables that I do not have on my farm, like tomatoes and cabbages since mine is still in the infancy stage, courgettes, and potatoes. As for cereals, I stocked up in March since they have shelf-life, the fruits depend on seasons, oranges at the moment are cheap, four for $20.000 \mathrm{KES}$, then I buy watermelons, pawpaws, and pineapples."

She continued to express that nutrition is essential for her. She also purchases herbs that she does not have on her farm; she stated: "Back in March, I bought cloves, cinnamon, turmeric, and now weekly I buy ginger and garlic to make herbal drinks."

The nutritional awareness, the know-how of variety of food preparation, alongside income earnings, determine some families' consumption. An older woman aged 85 years and living alone, with all her children married in the city, still ate the same nutrition-rich foods as before. She said:

"My daughters brought all the necessities, cooking oil (sunflower oil), atta wheat flour, brown rice, and brown maize flour as well, I cook for myself, and for my tea in the morning I eat with arrowroots or ugali (Kenyan main meal made from boiling maize flour)."

Hence, for the elderly who had children working in the middle to high-income jobs in the cities, they enjoyed the same lifestyle as before. Her children had stable government jobs for the older woman, and the ease of mobility was enabled by their private cars.

The changes in prices of goods have affected the farmers and shop owners in the villages in Murang'a. When these villages' residents opt to purchase some products over others, the shop keepers cut out some products by not restocking or only stock fewer supplies due to lower demand. A greengrocer owner in a local market in Gatanga shared his observation of the customers' preferences, he said: "Some of the cereals mostly purchased are maize and beans since that is the staple food here, in fact in the whole of Kenya, I am sure." 
The other cereals, which are quite expensive and only consumed by low-income families on occasions, have, for the moment, reduced demand; however, some families still purchase them for nutritional factors. The cereal prices were unaffected by COVID-19 restrictions as they were in season; however, their consumption was a luxurious venture to many low-income families. These cereals included Kenyan black beans (njahi) whose prices change during the off-season and in-season from 120 KES to 60 KES per $\mathrm{Kg}$, respectively, green grams or mung beans (ndengu), which go for $150 \mathrm{KES}$ per $\mathrm{Kg}$, and brown lentils (kamande), which cost $200 \mathrm{KES}$ per Kg. Among the three kinds of cereal, the least bought are brown lentils, with only high-income and middle-income families affording to purchase.

The family lifestyle of three, mother, daughter, and father, has not changed as much, owing to small family size, daughters' young age, and the family, although reduced, still had a continuous income flow. The mother, a shopkeeper, sells household necessities in the inner parts of the village; she is also a farmer of tea, vegetables, and avocados as detailed her observation, she said: "Many people have reduced consumption of products like sugar, bread, and flour; they have also substituted the buying of cooking oil with cooking fat, which is cheaper."

Despite the decline in demand for those products, staple foods are still purchased regardless of the increase in prices, such as beans, maize flour, rice, and tea. The shopkeeper's husband is employed in butchery at the local market area and pointed out that meat prices have remained the same in the Gatanga area; however, many people no longer buy meat, she said: "One slaughtered cow at the butchery is taking a week to be finished, and for other meats like mutton and pork, the demand is even lower because usually, beef is always the cheapest."

In Kenya, beef is the cheapest, most affordable meat; however, for low-income families, meat consumption is a luxurious encounter. Table 1 illustrates the prices of goods as recounted by the shopkeeper in a village in Gatanga.

Table 1.

Prices of Grains pre- post Covid-19

\begin{tabular}{lccc}
\hline \multicolumn{1}{c}{ Products } & $\begin{array}{c}\mathbf{2 0 1 9} \\
\text { (Price per Kg) }\end{array}$ & $\begin{array}{c}\mathbf{2 0 2 0} \\
\text { (Price per Kg) }\end{array}$ & $\begin{array}{c}\text { Increase } \\
\text { (\%) }\end{array}$ \\
\hline \hline Beans & $70 \mathrm{KES}$ & $100 \mathrm{KES}$ & $43 \%$ \\
Maize Flour & $50 \mathrm{KES}$ & $70 \mathrm{KES}$ & $40 \%$ \\
Rice (pishori) & $140 \mathrm{KES}$ & $170 \mathrm{KES}$ & $21 \%$ \\
\hline \multicolumn{4}{c}{ Source: Primary research data }
\end{tabular}

\section{Economic shock}

Economic shocks are an economic phenomenon where there are difficulties in terms of the economy. Chakrabarti (2014) stated that economic shocks present a sudden and unexpected threat. Economic shocks are also unable to provide anything competitive. In addition, economic shocks involve short- term capital constraints, economic recession, and uncertainty. Previous studies have shown that economic shocks lead to an unpleasant life, so that many people tend to want to run away from the place (Becker et al. 2005, Curran et al. 2016, Hansen et al. 2020). Rose \& Mishler (2010) stated that economic shocks could cause a global economic crisis, which illustrates destabilization. This shock affected the lower class; however, the upper class also significantly experienced the same thing. Previous studies have also stated that economic shocks lead to high unemployment and slow recovery (Compton et al. 2014, Ray et al. 2016, Watson \& Deller 2017).

Hobbs's (2020) theoretical studies pointed out that demand shock inflicted a necessity of adjustment in food supply chains; these shocks arose from panic buying and new food purchasing patterns. The shocks also called for preparedness to disrupt supply resulting from labor shortages and transportation network disruptions. Hobbs (2020) discussed the effects of prolonged demand shock as emerging from 
lower consumer incomes and product preference shifts, which, for instance, cause consumers to forego buying expensive items.

In this study, as discussed in the lifestyle changes of the Gatanga residents in Murang'a County, many of the residents have opted to purchase certain food commodities over other foods. The grocery store owner also pointed out that many no longer purchased fruits he said:

"Oranges are in season right now, and are very cheap, so the demand is higher compared to other fruits like watermelon; however, some families buy a few fruits to be eaten at a go and not throughout the week due to inability to afford more."

It indicated that low-income families would not afford the nutrition value of fruits at this volatile time. The increase in product prices will undoubtedly be on those products considered high-value products, such as meat and perishables (Siche 2020). The mother of 12 children pointed out that milk prices had gone down she said:

"With schools and many restaurants closed, the demand for milk is low, so prices had to be slashed; however, for eggs and chicken, prices are high despite low demand owing to the closure of restaurants."

The teacher or farmer, however, stated that rural prices differ from urban prices: "Some of the farm products are cheap here; however, prices may double when they reach the city." The prices of products like sugar and wheat flour had remained the same; however, their sales had lowered as per the shopkeeper's observation.

\section{Changes in farm gate prices}

Siche (2020) named small farmers as the second vulnerable group as they find challenges to access the markets to sell their products and buy farm inputs. It is the case for macadamia farmers in Gatanga, probably even the whole of Murang'a. With the uncertainty and slashed export quantities of products, the demand for macadamia nuts sales has decreased. One of the farmers classified her sales this year as unprofitable:

"In March, I sold my nuts for 70 KES per Kilogram, which was a decline from 135 KES last year, and as of now, in June, I am still looking for buyers. The trees are heavy with nuts, and the local market is not as high as the previous abroad, so most of us are selling one Kilogram at 40 KES, which is a giveaway price, not fruitful; however, it is better to sell than not to."

It indicates that the farmers are cutting their losses; even without the expected high returns of the world's most expensive nuts, the little they make will go a long way instead of wastage. Prices of macadamia were per $\mathrm{Kg}$, avocados were one avocado at (given price), and arrowroots were three arrowroots at (given price). Figure 2 shows how prices had taken a downward slope from 2019 to when the first coronavirus case was announced in March 2020. The percentage changes between 2019 and recent June 2020 prices of macadamia, avocados, and arrowroots were $70 \%, 75 \%$, and $40 \%$, respectively; however, macadamia prices in 2019 were fluctuating with 135 being the peak season and off-season rising to even 200 KES.

All the farms owned by the respondents had avocado trees and macadamia trees, even though some only had a few. Macadamia farmers and avocado farmers witnessed significant losses; however, before coronavirus's unwarranted effects of lockdown measures where the farmers were not fairly compensated for their produce due to long supply chains of distribution, the returns had been bountiful and satisfying. The shopkeeper who owns three macadamia nut trees announced that: "One tree can give you even over 4000-5000 on a good year." 
It was also the case for all the other macadamia farmers. Compared to other avocado transporters, Kenya only exports $10 \%$ of total production, whereas countries like South Africa export $60 \%$. In addition, the production for export was declining before COVID-19 export cut-offs. This challenge arises from low quality, incapacitated institutions of small-scale farmers, high regulatory standards in the export market, insufficient capacity, and co-ordination of fruit exports (Amare et al. 2019). Muthoka et al. (2008) found that a macadamia tree can yield 10-20 Kg per year in small-scale farms, while in medium and large farms, where acceptable agronomic practices have been adopted, it can yield $80 \mathrm{Kg}$ per year. Some markets had been closed down when the first cases were reported, flights had been reduced, and exports reduced if not canceled. It has been noted that demands for macadamia nuts are higher than actual sales. The teacher or farmer stated:

"I would like to think macadamia nuts, despite their health benefit at the moment, are not a priority in the market, because, at the end of March, we sold our nuts at a loss, only $70 \mathrm{KES}$, and right now, in June, I am struggling to find buyers; most of us are now selling at 40 KES."

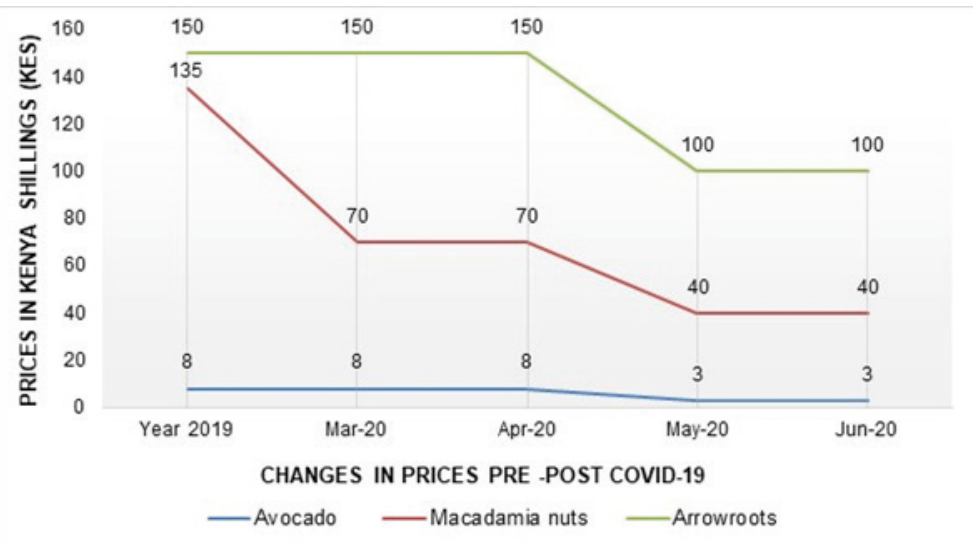

Figure 2.

Decrease of farm gate prices

Source: Primary research data

These are considerable losses in considering macadamia nuts being the world's most expensive nuts selling at 25 USD per 454 grams in international markets where China and the United States are the biggest consumers, around 2.600 KES (Kim 2019). The nuts' slow harvesting, which is through handpicking and slow growth of about 7-10 years for the first yield, contribute to the high prices. Prices of banana and cabbage are not in $\mathrm{Kg}$, however, per item. Figure 3 shows that the percentage changes in farm gate prices between the year 2019 and the recent June 2020 prices of bananas (small cluster), bananas (large cluster), cabbage (one large cabbage), and maize per $\mathrm{Kg}$ are $100 \%, 75 \%, 75 \%$, and $40 \%$, respectively.

The prices of banana branches, cabbages, and sacks of maize increased while others went down. Fischer and Qoim (2011) noted that the demand for dessert bananas in Kenya had grown; hence, small- scale farmers had developed a reliance on cash income from banana sales. The banana sellers were still joyous of the profits made, especially from hiked prices. Usually, bananas are purchased by traders who sell in cities. The majority of the homes, as recounted, had their supply of vegetables; hence they only needed to purchase beans, rice, and maize flour. Those who had previously had a good harvest of maize in the last season, and had effectively dried it in the granaries, were able to grind the maize into flour at a local miller.

The economic shock was experienced by all the residents of the Gatanga sub-County. The shocks materialized from all the new regulations associated with the lockdown measures, which had reduced access to markets, both local and international. The closure of restaurants in Thika and Nairobi Towns affected the demand for such farm products as milk, eggs, poultry, arrowroots, and sweet potatoes. The 
roadside sale of roasted maize in cities had also gone down, yet the traders used to buy their maize in these rural areas. Then, the effects of heavy rains that caused flooding and landslides and hindered the flow of transportation systems, and affected maize's drying process was a cost high to pay alongside the production losses from COVID-19 mitigation. However, with the recent opening of some previously closed Thika town markets and the fumigation of local markets in the county once every three days (Munyao \& Wanjiru 2020), there is hope for continued sales; a loss or profit is still inevitable. So far, food is still plenty; however, the aftermath of what the impact on the agricultural sector will become is gradually unveiling itself.

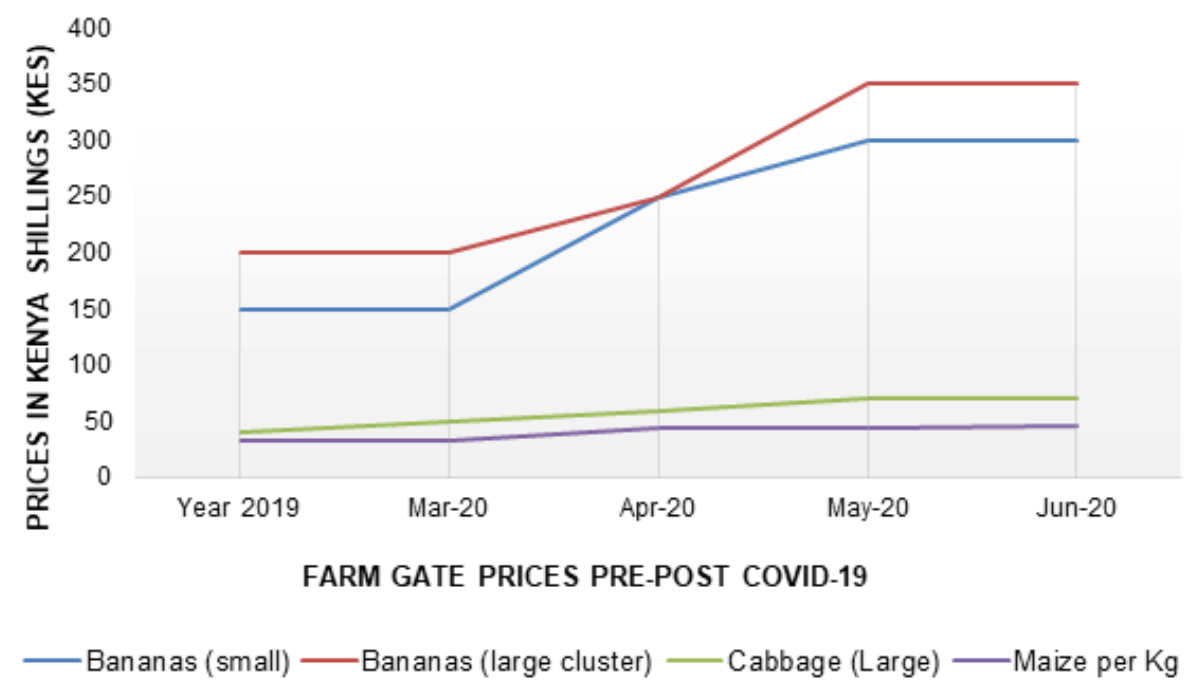

Figure 3.

Farm gate prices pre-post Covid-19

Source: Primary research data

\section{The scarcity of food commodities}

A commodity is considered scarce if it is limited in availability and has greater utility levels. Hence the commodity has a high use-value; however, is only available in fewer quantities. To draw a clearer picture, scarce being placed hand in hand with resource symbolizes that a resource has limited availability relative to desired use and is, thus, subject to economic analysis. Kenya's agriculture sector's stability has fallen prey to the COVID-19 effects and the unexpected heavy flooding, landslides, and some parts have unfortunately experienced an attack on crops by locusts.

Research has revealed that agricultural activities are susceptible to uncertain events like climatic changes, economic shifts, pests, and diseases. An individual household's adaptive capacities determine climatic vulnerability. The impact of climate change is also determined by the magnitude and extent of households affected (Dharmawan \& Nissa 2020). Such is the case of flooding, landslides, and earth movements in Kenya during the heavy rains in April, May, and even June; however, not all families were adversely affected, while others displace amid the COVID-19 scare.

In Gatanga, with most highlands regions, the valleys filled up and flooded, and many crops near the streams or valleys destroy; all the farmers in this study reported witnessing crop destruction in their farms. The shopkeeper's farm also had undergone a mild landslide:

"Some parts of my land separated, leaving deep holes that I covered with soil; however, it didn't cause much damage, unlike the floods in ngurumo (downhill), my arrowroots soaked in too much water, my maize too and my vegetables were carried away by the overfilled stream." 
Ngurumo is a Kikuyu reference to the farm at the bottom of the hill located next to a valley, usually wetland, and is excellent for arrowroots and vegetables and maize in the drier upperparts. Waithera (2020) showcased images of acres of tea farms that had been swept away by rain as the county meteorologist concluded that the rains had surpassed the soil saturation capacities. Other sub-counties in Murang'a experienced mudslides, which hampered transport operations, earth movements, cracks, swelling of the Chania and Thika rivers, and the overflowing of dams like the Ndakaini dam in Gatanga sub-County.

Fertilizer shortages will be experienced this year with halted imports of fertilizers as well as delays. As recently as 16 June 2020, the Kenya Tea Development Agency (KTDA) announced the cancellation of fertilizer importation for small tea holder farmers. The importation will be suspended till the following season and will affect about 600.000 tea farmers. It will force the tea farmers to buy the fertilizer at market prices, double the subsidized prices provided by the KTDA co-operation. Usually, the fertilizers are imported to boost the plants in short rains seasons in October and November. The organization blamed the exportation disruptions of COVID-19 for the inevitable delays in fertilizers importation (Kenya CitizenTV 2020).

In August 2019, KTDA imported 45.000 metric tonnes of NPK (Nitrogen, Phosphorus, and Potassium) fertilizers, while the first consignment of 50.000 metric tonnes had arrived in June 2019 (NTV Kenya 2019). This importation of fertilizers benefit over 600.000 small farm holders had already been successfully implemented in 2015 as well; hence a trend of dependency had begun among the small farmers. In 2015, as reported in KTN Prime News, the first organization, KTDA, procured a consignment of a total of 77.000 tonnes of fertilizers, showing that, yearly, the tonnes imported continued to rise; however, the prices of fertilizers as reported in April 2020, were still dormant, (KTN News Kenya 2015; WFP 2020). Some of the farmers had heard this on the radio, and others watched on the TV; the five small-scale farmers, the shopkeeper, the mother of 12 children, and the older woman were all tea farmers who had enjoyed this generous benefit. The mother of 12 said: "Now, we have to buy the fertilizers at the agro vet, and the retail prices are very high, more than 1.000. We only used to be charged one or two KES a month."

The scarcity of food commodities can emerge from reduced imports as a result of pandemic disruptions. It then fuels a hike in the prices of commodities (Ataguba 2020). For instance, in the Global South, rice prices had peaked to a record high compared to the last decades (Zurayk 2020). The same applies to maize prices in Kenya since maize is the primary determinant of Kenya's food security for most lowincome families. In 2013, the Food and Agriculture Organization (FAO) reported that Kenya imports about five times as much wheat as it produces. The main imports come from Russia and Ukraine, followed by the United States and Argentina. The fate of the Kenyan wheat surplus may be uncertain, considering that some countries like Kazakhstan, Romania, and Russia have imposed trade restrictions on primary food commodities, which is wheat, while Cambodia, India, and Thailand have done the same on the trade of rice. In other countries, like Argentina, the outbreak of coronavirus among food workers affected the supply of soy meal; however, the study noted that the past season had yielded in bulk; hence, reserves exceed regular demand (Zurayk 2020). This study uncovered that those living in poor livelihoods could no longer afford wheat products like bread, flour for chapatti, mandaazi, and ngumu (Kenyan snacks usually taken with tea). In 2012, the FAO also showed Kenya imports its rice from Pakistan, followed by Vietnam, Thailand, and a 4\% share from India. Rice is the third most staple food in Kenya after maize and wheat. Hence, Zurayk (2020) mentions that trade restrictions from Kenya's primary rice sources pose uncertainty of future surplus.

\section{Conclusion}

The study identified that social issues like lifestyle changes which impacted on change in consumption were as a result of ongoing and anticipated income shortages and priority changes; for instance, some vegetables are prioritized over others, cabbage over cucumbers, increased consumption as the whole families are at home, and loss of productivity due to floods. Farmers who had other professions were 
less prone to adverse effects of shifting living standards. Their lifestyle only slightly changed since their regular travel to cities to purchase such products as herbs and honey had become challenging. Nutrition of the majority of low-income homes is alarming; the need to eat balanced diets is no longer a priority compared to eating to curb hunger. Therefore, lifestyles have taken on a new normal, some slightly affected, mainly government-employed who still earn, and others adversely affected.

Thus, as predicted in other studies, the projections for the new normal, which is the era after the pandemic, suggest heightening situational and relative poverty worldwide, even in developed countries. The study recommends other research to evaluate alternative solutions to supply the county's food outputs other than those already in co-operatives, like tea, coffee, milk, and avocados. Perhaps the question for other future researchers should now be directed toward the vulnerable families' daily consumption quantities concerning balanced diets. Food scarcity in Kenya is caused by the COVID-19 pandemic and caused by massive floods, landslides, and locust pests. Meanwhile, in Gatanga, most areas are highlands and valleys so that agricultural areas are quickly swept away by flooding. On the other hand, farmers have difficulty obtaining fertilizers because of the policy to stop importing them, so that farmers pay twice as much for fertilizer, which causes farmers to spend more in economic activities.

\section{References}

African Business (2020) Kenyan tea offers green shoots amid coronavirus woes, 5 May. [Accessed 14 March 2020]. https://africanbusinessmagazine.com/sectors/agriculture/kenyan-tea-offers-greenshoots-amid-coronavirus-woes/.

Amare M, Mariara J, Oostendrop R, \& Pradhan M (2019) The impact of smallholder farmers'participation in avocado export markets on the labor market, farm yields, sales prices, and incomes in Kenya. Land Use Policy 88:104-168. https://doi.org/10.1016/j.landusepol.2019.104168.

Andae G (2020) Kenya in plan to import 2m bags of maize by May. The East African, 11 March. [Accessed 10 June 2020]. https://www.theeastafrican.co.ke/business/Food-agency-asks-State-toimport-2m-bags-of-maize/2560-5486688-op7fsl/index.html.

APA News (2019) Kenya: Fresh produce exports jump to $\$ 1.5$ bn in 2018, 12 February. [Accessed 10 June 2020]. https://apanews.net/en/news/kenya-fresh-produce-exports-jump-to-15bn-in-2018.

Ataguba JE (2020) COVID-19 pandemic, a war to be won: Understanding its economic implications for Africa. Applied Health Economics and Health Policy 18 (2020):325-328. https://doi.org/10.1007/ s40258-020-00580-x.

Barichello R (2020) The COVID-19 pandemic: Anticipating its effects on Canada's agricultural trade. Canadian journal of Agricultural Economics 68 (2020):219-224. https://doi.org/10.1111/cjag.12244.

Becker CM, Musabek EN, Seitenova AGS, \& Urzhumova DS (2005) The migration response to economic shock: Lessons from Kazakhstan. Journal of Comparative Economics 33 (1):107-132. https://doi. org/10.1016/j.jce.2004.12.003.

Chakrabarti A (2014) Organizational adaptation in an economic shock: The role of growth reconfiguration. Strategic Management Journal 36 (11):1717-1738. https://doi.org/10.1002/ smj.2309.

Compton WM, Gfroerer J, Conway KP, \& Finger MS (2014) Unemployment and substance outcomes in the United States 2002-2010. Drug and Alcohol Dependence 142 (2014):350-353. https://doi. org/10.1016/j.drugalcdep.2014.06.012.

County Government of Murang'a (2018) County integrated development plan 2018-2022. [Accessed 13 June 2020]. https://cog.go.ke/media-multimedia/reportss/category/106-county-integrateddevelopment-plans-2018-2022.

Curran SR, Meijer-Irons J, \& Garip F (2016) Economic shock and migration: Differential economics effects, migrant responses, and migrant cumulative causation in Thailand. Sociology of Development 2 (2):119-157. https://doi.org/10.1525/sod.2016.2.2.119.

Dharmawan AH \& Nissa ZNA (2020) Rural livelihood vulnerability and resilience: A typology drawn from case studies of small-scale farmers and fishermen in Indonesia. Sodality: Jurnal Sosiologi Pedesaan 8 (1):1-13. https:/doi.org/10.22500/8202028458. 
FAO (1996) Rome declaration on world food security and world food summit plan of action. [Accessed 8 June 2020]. http://www.fao.org/DOCREP/003/W3613E/W3613E00.HTM.

FAO (2006) Food security: Policy brief, 30 June. [Accessed 8 June 2020]. https://reliefweb.int/report/ world/policy-brief-food-security-issue-2-june-2006.

Fischer E \& Qoim (2011) Linking smallholders to markets: Determinants and impacts of farmer collective action in Kenya. World Development 40 (6). https://doi.org/10.1016/j.worlddev.2011.11.018.

Hansen HK, Lyngemark DH, \& Weatherall CD (2020) Migration and employment after an economic shock: Regional characteristics and migration patterns. Regional Studies, 1-14. https://doi.org/1 $0.1080 / 00343404.2020 .1814230$.

Hobbs JE (2020) Food supply chains during the COVID-19 pandemic. Canadian Journal of Agricultural Economics 68 (2020):171-176. https://doi.org/10.1111/cjag.12237.

Kenya CitizenTV (2020) KTDA halts imports of fertilizers for tea farmers. [Accessed 20 June 2020]. https://youtu.be/JgU3y3Cyyl4?t=2.

Kim IA (2019) What makes Macadamia nuts the most expensive nuts in the world, at $\$ 25$ per pound. Business Insider, 6 March. [Accessed 15 June 2020]. https://www.businessinsider.com/macadamianuts-most-expensive-world-australia-hawaii-2019-3.

Kimuyu (2020) June 24: Alarm as Kenya adds 254 new Covid-19 cases. Nairobi News, June 24. [Accessed 24 June 2020]. https://nairobinews.nation.co.ke/editors-picks/june-24-alarm-askenya-adds-254-new-covid-19-cases.

KTN News Kenya (2015) Small scale tea farmers to receive tonnes of fertiliser procured by KTDA. [Accessed 13 June 2020]. https://youtu.be/A11K2mwHQ2A?t=57.

Maphill (2011) Silver style simple map of Muranga. [Accessed 15 June 2020]. http://www.maphill.com/ kenya/central/muranga/simple-maps/silver-style-map/.

Meeme V (2020) Kenyan farmers take new approach to sales during COVID-19 lockdown. Cornel Alliance for Science, 14 April. [Accessed 8 June 2020]. https://allianceforscience.cornell.edu/ blog/2020/04/kenyan-farmers-take-new-approach-to-sales-during-covid-19-lockdown/.

Munyao B \& Wanjiru A (2020) Movement of people in and out of Murang'a County restricted. Kenya News, 24 March. [Accessed 9 June 2020]. https://www.kenyanews.go.ke/movement-of-peoplein-and-out-of-muranga-county-restricted/.

Murang'a County Government (2017) Agriculture and Agribusiness. [Accessed 13 June 2020]. https:// muranga.go.ke/?page_id $=3432$.

Muthoka NM, Kiuru PDN, Mbaka J, Nyaga AN, Muriuki SJN, \& Waturu CN (2008) Macadamia nut production and research in Kenya. The African Journal of Plant Science and Biotechnology 2 (2):46-48.

Njeru TN \& Ayieko MW (2020) Why COVID-19 is another blow for Kenya's food security. The Conversation, 20 April. [Accessed 9 June 2020]. https://theconversation.com/why-covid-19-isanother-blow-for-kenyas-food-security-135567.

NTV Kenya (2019) 45.000 metric tonnes of fertiliser imported by KTDA docks at Mombasa Port. [Accessed 13 June 2020]. https://www.youtube.com/watch?v=N3oMwrz0YnI.

Poudel PB, Poudel MR, Gautam A, Phuyal S, Tiwari CK, Bashyal N, \& Bashyal S (2020) COVID-19 and its global impact on food and agriculture. Journal of Biology and Today's World 9 (5):221.

Ray DM, MacLachlan I, Lamarche R, \& Srinath KP (2016) Economic shock and regional resilience: Continuity and change in Canada's regional employment structure, 1987-2012. Environment and Planning A: Economic and Space 49 (4):952-973. https://doi.org/10.1177/0308518x16681788.

Roussi A (2020) Kenya farmers face uncertain future as Covid-19 cuts exports to EU. Financial Times, 4 June. [Accessed 13 June 2020]. https://www.ft.com/content/05284de8-c19f-46de-9fe7482689be364b.

Siche R (2020) What is the impact of COVID-19 disease on agriculture? Scientia Agropecuaria 11 (1):36. https://doi.org/10.17268/sci.agropecu.2020.01.00.

United Nation (2015) Transforming our world: The 2030 agenda for sustainable development. [Accessed 13 June 2020]. https://sustainabledevelopment.un.org.

University of Minnesota Libraries (2010) Social Problems: Continuity and Change. Minnesota: University of Minnesota Libraries. 
Wahome C (2020) Women worst affected in Kenyan flower farms in wake of COVID-19 pandemic. Capital News, 27 May. [Accessed 9 June 2020]. https://www.capitalfm.co.ke/news/2020/05/ women- worst-affected-in-kenyan-flower-farms-in-wake-of-covid-19-pandemic/.

Waithera A (2020) Heavy rains destroy homes, cause landslides in Murang'a. The Star, 10 May. [Accessed 25 June 2020]. https://www.the-star.co.ke/counties/central/2020-05-10-heavy-rainsdestroy- homes-cause-landslides-in-muranga/.

Wasike A (2020) Coronavirus strikes farmers, fishermen in Kenya COVID-19 restrictions, external factors affect fish exports, food production in East African country. Anadolu Agency, 20 April. [Accessed 8 June 2020]. https://www.aa.com.tr/en/africa/coronavirus-strikes-farmers-fishermenin- kenya/1811159.

Watson P \& Deller S (2017) Economic diversity, unemployment and the great recession. The Quarterly Review of Economics and Finance 64 (2017):1-11. https://doi.org/10.1016/j.qref.2016.12.003.

WFP (2020) COVID-19 supply chain and markets update. April 30, 2020. [Accessed 8 June 2020]. http://documents.worldbank.org/curated/en/683141588084127834/Kenya-Economic-UpdateTurbulent-Times-for-Growthin- Kenya-Policy-Options-during-the-COVID-19- Pandemic.

World Bank (2020) Kenya economic update: Turbulent times for growth in Kenya, policy options during the COVID-19 Pandemic. [Accessed 9 June 2020]. https://documents.worldbank.org/curated/ en/683141588084127834/Kenya-Economic-Update-Turbulent-Times-for-Growthin-KenyaPolicy-Options-during-the-COVID-19- Pandemic.

Zurayk R (2020) Pandemic and food security: A view from the Global South. Journal of Agriculture, Food Systems, and Community Development 9 (3):17-21. https://doi.org/10.5304/ jafscd.2020.093.014. 